\title{
On postsocialist capitalism
}

\author{
Nina Bandelj ${ }^{1}$
}

(C) Springer Science+Business Media Dordrecht 2016

\begin{abstract}
Unlike recent tendencies to specify the variety of postsocialist trajectories, this article attempts to characterize the common features of postsocialist capitalism, as it has developed since the 1990s in Eastern Europe. Using conceptual tools of economic sociology, the postsocialist socio-economic organization is analyzed as embedded economy, the institutionalization of capitalism as a moral project, and the pervasiveness of informality from the networks and culture perspectives. Economic development is viewed as dependent, simultaneously, on the system's structural, political and cultural features. For postsocialist capitalism, these features include lack of state autonomy due to close coupling of political and economic roles; the embrace of greed and self-interest as legitimate motives for action; and persistence and bolstering of informality as modus operandi. Stipulations about developmental consequences are provided in the conclusion.
\end{abstract}

Keywords Political and economic transformation · Eastern Europe $\cdot$ Embedded economy $\cdot$ Moralized markets $\cdot$ Informality as modus operandi $\cdot$ Development

Scholarship on the socio-economic changes after the communist transitions in Eastern Europe has focused on the intra-regional differences in development, inspired by the literature on the varieties of capitalism (Hall and Soskice 2001) to specify varieties of postsocialist capitalism (King and Szelenyi 2005; Feldmann 2007; Noelke and Vliegenthart 2009; Bohle and Greskovits 2012; Bruszt 2012). In contrast, the present article proposes to bracket the obvious cross-country differences and to challenge the received wisdom, asking if, possibly, we can identify some common institutional features for countries, which underwent relatively rapid simultaneous political and economic transformations from socialism to capitalism. ${ }^{1}$ The article does so by applying conceptual

\footnotetext{
${ }^{1}$ The emphasis is on rapid simultaneous political and economic transformations toward a capitalist democracy, which means that the scope of countries discussed here does not include countries of Central Asia and South Caucasus, nor China, Vietnam, and Laos.
}

Nina Bandelj

nbandelj@uci.edu

1 University of California, Irvine, 3151 Social Science Plaza, Irvine, CA 92617, USA 
tools of economic sociology to understand macro-development, as called for recently by Schrank (2015).

As such, the analysis rests on the understanding of socio-economic systems as embedded economies (Polanyi 1957; Krippner and Alvarez 2007; Bandelj and Sowers 2010), which conceptualizes economy not as a domain separate from society but constituted by social and political forces. The analysis also employs the notion of moralized markets (Fourcade and Healy 2007), where capitalism is seen as a cultural phenomenon and a moral project. In its discussion of informality, the analysis relies on the core economic sociological idea of networks and their potential downsides (Granovetter 1985; Portes and Sensenbrenner 1993; Uzzi 1997; Schrank and Whitford 2011) but also the cultural notion of informality-as a-way-of-doing-things ${ }^{2}$ in a sense of a moral imperative (Borocz 2000). Overall, the joint application of conceptual tools of embedded economies, moralized markets, and informality, is meant to emphasize that economic development in postsocialism should be understood and analyzed as dependent, simultaneously, on the system's structural, political, and cultural features.

I want to propose that something endemic to the rapid transformation of political and economic regimes during a period of neoliberal globalization - indeed, a simultaneity of privatization, deregulation, democratization, and neoliberal globalization as was the historic moment of postsocialist transformations-breeds characteristics of a distinct postsocialist capitalism. ${ }^{3}$ I want to explicate postsocialist capitalism as an ideal type in a Weberian sense, as an analytical lens to be judged against the empirical reality and not intended to capture the necessarily different manifestations in various postsocialist countries. In my characterization of postsocialist capitalism, I do not consider capitalism as resulting from self-driven mechanisms of surplus extraction and accumulation governed by objective laws, as either neoclassical or Marxist accounts would have it. I conceptualize capitalism as a set of interrelated social institutions, understood as formal and informal rules and practices, yielding a particular social, political, and moral organization of economy. As such, capitalism is a politico-cultural-economic system, where economy and society are intertwined and co-constitutive, rather than separate spheres (cf. Zelizer 2005).

Similar to Streeck's (2010) analysis of capitalism-writ-large, I develop a "heuristic checklist," drawing attention to characteristics that can be usefully considered to aid understanding of the processes and consequences of postsocialist transformations. The features outlined are not exhaustive, but, in my view, are central enough to be distinctive. As Streeck (2010, p. 4) notes, a "Weberian ideal type presents a simplified, abstracted image of the world that is not necessarily disproven by the fact that it does not include everything that exists in it. What matters is that it captures what is essential, and that the differences between it and the real world are peripheral for the latter or from the point of view of the investigation."

I argue that for postsocialist capitalism, such a heuristic checklist should include the following features: a) lack of state autonomy due to close coupling of political and economic roles, b) the embrace of greed and self-interest as legitimate motives for

\footnotetext{
${ }^{2}$ I thank a reviewer for suggesting this formulation.

${ }^{3}$ Note that I do not mean to imply that lived socialism was uniform in its expression across all of the countries under discussion here.
} 
action, and c) persistence and bolstering of informality as modus operandi. In what follows, I first briefly review prevailing approaches to development in postsocialism, then discuss each of the proposed features of postsocialist capitalism by applying conceptual tools of economic sociology. The conclusion provides some stipulations about developmental consequences.

\section{Prevailing approaches to development in postsocialism}

Theories proposed to explain the economic performance of Eastern Europe since 1989 have focused mostly on structures and politics. The focus on structures comes in three forms: either as an emphasis on market reforms and how quickly they need to be implemented; as an emphasis on the importance of market institutions and rule of law; or as singling out the weight of initial conditions such as industrialization, or precommunist characteristics. The focus on political factors privileges shifts in power elites (such as in initial elections), influence of civil war, or state breakup on the level of political instability and therefore uncertainty that stalls economic performance or drives resources away from productive activities, all pointing to the economic costs of political change and conflict. An analysis focused on institutional complementarities highlights the role of legacies and initial choices, as well as international forces and domestic politics in shaping the variety of East European capitalism (Bohle and Greskovits 2012).

One of the hottest, if now somewhat trite, debates about early postsocialist developments was about the consequences of two divergent approaches to postsocialist transformation, "shock therapy" reform - in which liberalization and privatization are undertaken simultaneously, speedily, and comprehensively — and a gradualist approach, that considers the institutional remains of socialism and time required to build new institutions. Neoliberal economists from the West who offered advice to formerly communist countries argued for hasty and holistic changes, with a goal of creating markets quickly by eliminating state command of the economy and wiping out the supposed irrationalities of redistribution. These advisers emphasized that the most efficient way of organizing an economy is by means of a self-regulating market, and so they encouraged societies that had ousted communists to develop a private property rights regime swiftly through mass privatization. According to economic theory, the release of price and currency controls, the withdrawal of state subsidies, and the liberalization of trade would act to give rise to an economic system largely free of governmental control. That new system, then, was to be coordinated by market prices and competition, with a clear incentive structure inducing efficient corporate governance and a rapid restructuring of firms (Boycko et al. 1995).

Advocates of the gradualist approach, on the other hand, criticized shock-therapy recommendations for their authors' assumption that externally manipulated alterations could be induced into these economies as if on a tabula rasa foundation. These analysts argued that the removal of the Party and socialist institutions did not result in an institutional vacuum into which new institutions could be inserted de novo; they also questioned the premise that market institutions could be designed via a blueprint at the systemic level. To this second group of specialists, the process of change was not about destruction and rebuilding ab initio but rather about a piecemeal construction of market 
institutions, which would take time and require the state to play a role. The process would also depend on experimentation and evolutionary learning and incorporate existing social and economic networks and practices (Stark and Bruszt 1998). As sociologist David Stark (1996) famously put it, capitalism was built with the ruins of socialism. Markets were not expected to "spring up as soon as central planning bureaucrats vacate the field" Sachs (1993, p. xxi). States were expected to play a critical role in ensuring private property rights but also regulating enterprise restructuring (King and Sznajder 2006), providing institutional underpinning for consumer markets (Guseva 2008), and institutionalizing the demand for foreign direct investment (Bandelj 2009).

As dramatic and relatively rapid changes in the region ensued, observers noted that they provided breeding ground for political capitalism (Staniszkis 1991) and corruption. Stiglitz (2000) argued that rapid privatization, as per neoliberal advice, brought about information asymmetries and lack of an effective governance framework. This was breeding ground for corruption as incentives and opportunities to pursue rentseeking and asset-stripping were manifold. Corruptive tendencies were exacerbated by additional neoliberal reforms: the liberalization of capital accounts facilitated transferring money abroad, and strict monetary policy encouraged predatory behavior because high interest rates prevented new firm owners from attracting capital needed for restructuring. All of this led to economic declines, particularly notable in Russia and the former Soviet countries. Burawoy (1996) interpreted this as the collapse of the socialist state in Russia that resulted in an "economic involution" (p. 1105), which he described as a process in which firm managers failed to utilize state subsidies to increase production, opting instead to pursue asset-stripping and transfer of wealth out of the economy. Others noted how all this brought anarchy to production while introducing barter alongside market exchange in the process (Woodruff 1999; Southworth 2004), and documented how Russian nomenklatura engaged in predatory practices during insider privatization (Nolan 1996; Frye 2000; Hough 2001; Rutland 2001; Barnes 2006).

King and Szelenyi (2005) noted that a larger subset of postsocialist countries exhibited these predatory features and called them neopatrimonial, in contrast to what they termed the neoliberal system that unfolded in Central Europe. But the question to which I will return is: Have the neoliberal postsocialist systems really avoided political opportunism, rent-seeking, and asset-stripping? Or does the systemic change from socialism to capitalism during neoliberal globalization - where rapidity and simultaneity of economic and political change breeds conditions of partial reform, where practices of informality consolidated in socialism define logics of path-dependent development and neoliberal legitimization of greed (Streeck 2010) is added to the mix-make such practices endemic to these systemic transformations, so that the distinction across the broader region is really a matter of degree rather than kind?

Moreover, while most analyses have focused on whether the neoliberal advice was well placed or not by examining the economic consequences of mass privatization, deregulation, and liberalization, only few have considered that the fervent belief in the power of free-markets - which lies at the very core of neoliberal advice - is a moral project (Fourcade and Healy 2007). The neoliberal policy prescriptions for the postSoviet bloc say as much about the kinds of structural reforms that need to be implemented to unleash markets as they do about the kinds of behaviors that 
postsocialist economic subjects ought to engage in to become market actors proper. Such disciplining of postsocialist capitalists was no doubt set in motion because post1989 changes were happening in a global environment that promoted the Washington Consensus (Williamson 1993; Gore 2000) and was bolstered by the fact that neoliberalism has endogenous roots in socialism (Bockman and Eyal 2002; Bockman 2011).

Eschewing the analysis of postsocialist capitalism as a moral project, scholarship zeroed in on the necessity of the formal institutional framework for markets (Stark 1992; Burawoy 1996; Stark and Bruszt 1998; McDermott 2002), but also on how neoliberal reforms directly undermine it. On this point, Hamm and colleagues (2012) investigated the impact of mass privatization on economic performance in the first decade after 1990. The authors argued that implementing mass privatization, measured as the use of voucher or management and employee buyout methods to privatize more than $25 \%$ of formerly state owned assets, undercut taxation and state revenue, leading to the breakdown of state capacity and deeper recessions. The emphasis on the link between an effective state and economic development aligns with a Weberian tradition on development (Evans 1995; Evans and Rauch 1999). It is also in line with seeing the great postsocialist transformation to market order as instituted by the state (Polanyi 1944). Following these conceptual threads, the first feature of postsocialist capitalism that I want to identify interrogates the kind of relationships among society, state, and economy (Block and Evans 2005) that have emerged in postsocialist countries.

\section{Postsocialist embedded economies: state (in)capacity and (lack of) state autonomy}

That states play a central role in market building is a central premise of a Polanyian analysis of capitalism, also captured in his notion of embeddedness (which I call embedded economies, to differentiate it from Granovetter's (1985) definition of network embeddedness in economic sociology). Likewise, the concern for the state's role in development goes back to Weber's understanding of modern capitalism and the claim that successful capitalist development requires not just markets but the presence of a strong, bureaucratic state (Wade 1990; Evans and Rauch 1999). To best serve the needs of modern capitalist firms, the state's behavior must be predictable on the basis of formal rules of administration, a rational legal system, and accountable civil servants (Weber 1978; see also Collins 1980). Conversely, if such a state is unavailable, for Weber, "adventurous and speculative trading capitalism and all sorts of politically determined capitalisms are possible, but no rational enterprise under individual initiative, with fixed capital and certainty of calculations" (Weber 1978, p. 25).

Weberian states have state capacity, defined as the ability of a government to administer its territory effectively (Skocpol 1985). State capacities include "the capacity to mobilize financial resources from the society to pursue what the central policymakers perceive as the 'national interest' (extractive capacity); the capacity to guide national socioeconomic development (steering capacity); the capacity to dominate by using symbols and creating consensus (legitimation capacity); and the capacity to dominate by the use or threat of force (coercive capacity)" (Wang 1995, p. 92). In contrast, weak, non-bureaucratic states are characterized by widespread corruption, as patron-client networks begin to permeate their organization, and the separation of officer-holder and 
office becomes indistinct. In such an environment, rent-seeking politicians allow economic elites to influence political and economic decisions in exchange for bribes. In the worst case of a predatory state assets and state revenues are largely stripped by the ruling elite (Evans 1995).

State autonomy (Evans et al. 1985, p. 5), i.e., the fact that states can "formulate and pursue goals that are not simply reflective of the demands or interests of social groups, classes, or society" is another important institutional feature that shapes development. Evans (1979) coined the term "embedded autonomy" as a characteristic of a developmental state, which characterizes an autonomous and capable state that establishes collaborative relationships with business actors in society. States are embedded in local capital through the close social ties between state bureaucrats and domestic business owners and managers. However, states retain their autonomy because of the presence of a classic Weberian bureaucracy, based on meritocratic recruitment and promotion and norms of objective procedural rationality. In contrast, a predatory state ruthlessly extracts from society and provides nothing of value in return. Here, the preoccupation of the ruling class is rent-seeking, using the state apparatus to amass personal fortunes. Instead, capable and embedded but autonomous states can provide fertile conditions for economic growth by defining and enforcing property rights, providing transparent and accountable market institutions, including adequate legal and regulatory frameworks, and support nascent domestic industries or new technology development (Block and Evans 2005; Bandelj and Sowers 2010).

This said, the challenge to build capable developmental states in the shift from socialism to market seems nearly insurmountable. Transformation from collective ownership and redistribution to private property rights and market exchange is a daunting task. Even in cases of mass privatization or with very swift and peaceful relinquishing of the Party grip, the system transition is not something that can happen rapidly. Instead, the shift necessarily causes a state of partial reform where the door is open to market mechanisms but the state still holds its foot in the redistributive system. In this postsocialist purgatory, an in-between state, conflicts for control over productive assets arise, contract enforcement becomes uncertain, and state revenues are undermined. This is breading ground for the first feature of postsocialist capitalism that I want to highlight: lack of state autonomy, a differentia specifica to embedded autonomy. ${ }^{4}$

The condition of partial reform, the grey zone of neither socialism nor capitalism, seems inevitable when institutional changes are implemented quickly and broadly. As Nee and Lian (1994) proposed for the case of China, such a situation increases the payoff to opportunism (even absent the moral imperative of neoliberal capitalism, which I discuss next). The expansion of markets opens up new opportunities to amass personal wealth. Under partial reform, however, control over many critical resources is retained by state agencies compelling managers to cultivate ties with bureaucrats (Nee and Lian 1994) and bureaucrats to take advantage of economic opportunities in markets. These conditions also provide advantages to what we could call "postsocialist brokers" who maneuver the overlapping space between the state and the market sectors to their advantage. On the whole, those who occupy positions in both the state and the marketized sectors, enjoy clear advantages over those whose activities are limited to

\footnotetext{
${ }^{4}$ I thank a reviewer for this formulation.
} 
either just the state or the private economy, as the notion of brokerage from network analysis clearly implies (Burt 1992, 2004). As many studies of postsocialist mobility demonstrate, cadres used positional power to their advantage by turning political capital into economic capital (Rona-Tas 1994; Gerber and Hout 1998). The political and economic spheres become literally coupled as the same people (or their relatives and friends) occupy both political and economic roles (cf. Stark and Vedres 2012). In addition, new private actors, without pre-existing links to the political elite, maneuvering the uncertain institutional terrain, can take advantage of nontransparency, information asymmetry, and lack of the rule of law, especially if informality-as-a-way-of-doingthings learned during socialism guides their behavior. Moreover, all are encouraged to take advantage of any economic opportunity because of the increasing legitimacy of profit-seeking and greed, as part and parcel of moral project of neoliberal postsocialist capitalism, a feature to which I turn next.

\section{Postsocialist capitalism as a moral project: legitimacy of greed}

In his analysis of capitalism, Streeck (2010) returns to "a more traditional concept of capitalism, one in which two fundamental motives of human action, greed and fear, loom large" (cf. Bohle and Greskovits 2009). He observes that in the past two or three decades, as capitalism "extricated itself from the social-democratic regime imposed on it after 1945, it became more like itself, revealing in the course of its development its "true nature," or its "essence." In the words of Glyn (2006), capitalism became unleashed, and globalization helped this process. As Streeck (2010, p. 28) concludes:

In the neo-liberal era, which was also one of 'globalization', capitalism became progressively more capitalist as its inherent tendency of development unfolded - its drive to break out of the social-institutional arrangements that both contain and sustain it - posing new and historically unique challenges for a politics of social reconstruction that is condemned to be always caught off guard by the cunning restlessness it is supposed to keep under control.

Postsocialist transformations coincided with the rise of neoliberal globalization, which is a unique characteristic of this transition to capitalism compared to other places at other times. Streeck's (2010) discussion suggests that this stripped down version of global neoliberal capitalism, this unleashed form, with its basic tenets of greed and fear, was embraced-greed with eagerness and fear with resignation - in postsocialist countries. But this embrace came without a mature formal institutional system on which capitalism otherwise rests, without clearly defined property rights, without transparency, and accountability as predicated by the rule of law. That is, capitalist dogma of legitimate greed and self-interest was embraced without the requisite market institutions in place. This is one major contradiction of postsocialism: the legitimization of greed without formal institutional foundations of capitalism. While the neoliberal project in postsocialist countries may have apparently failed because of the slowness of reform (at least slower than initial advisors recommended), it has nevertheless succeeded as a moral project that shaped central aspects of postsocialist subjectivity. Not only did the systemic condition of partial reform provide opportunities for self-serving behavior, the 
cultivation of legitimate greed enabled advantaged postsocialist actors to interpret such behavior as normatively appropriate and, therefore, to engage in such behavior. This is a different understanding of why predatory and corrupt practices abound in postsocialism. It does not rely on a notion that self-interest is an inherent drive that waits to be unleashed when state bureaucrats vacate the field. It is a proposition that the moral project of postsocialist capitalism helped create the kind of capitalists that, when presented with a structural opportunity, acted in a particular way and not otherwise. ${ }^{5}$ The resulting behavior we have witnessed is the same, but the theory of action behind it is starkly different.

Moreover, despite the neoliberal recommendation that the major challenge to postsocialist economies is the need to depoliticize them (and withdraw the state from the economy), what in fact was facilitated by partial reform and simultaneity of political and economic transformations was increased coupling of political and economic roles leading to a significant overlapping of the private and state spheres. Further, the new moral order, resting on the belief in and pursuit of self-interest, led to what we could call de-socialization of economy, eschewing collective responsibility for social welfare. The norms that are required for effective economic governance (Ostrom 1990) are lacking, and coordination exists in clientelistic and oligarchic forms that rely on reciprocal relations within cliques but are predatory against the system as a whole. This is a state of anomie in Durkheimian terms, i.e., lack of social regulation as would occur in any period of abrupt systemic changes (Durkheim 1951), but - given that severing of all ties to the past is not possible - social integration remains grounded in old informal networks and in old socialist ways of circumventing rules to get by. This brings us to the third central feature of postsocialist capitalism: the moral imperative of informality.

\section{Informality: social relations in economy and moral imperative of informality}

Relations of reciprocity and marketlike transactions were widespread inside the social sectors as well as in the 'second economy' and stemmed from the contradictions of attempting to 'scientifically manage' an entire national economy. At the shop-floor level, shortages and supply bottlenecks led to bargaining between supervisors and informal groups; at the managerial level, the task of meeting plan targets required a dense network of informal ties that cut across enterprises and local organizations; and the allocative distortions of central planning produced the conditions for the predominantly part-time entrepreneurship of the second economies that different in scope, density of network connections, and conditions of legality across the region.... The existence of parallel structures (however contradictory and fragmentary) in these informal and interfirm networks that 'got the job done' means that the collapse of the formal structures of the socialist regime does not result in an institutional vacuum. (Stark 1996, pp. 994-995)

\footnotetext{
5 This implies very conscious decision-making on the part of actors, generally. Two caveats are in order: for one, many simply mimicked the behavior they saw around them, and second, many obviously never got any of these self-advancing opportunities to take advantage of, which contributed to vastly expanding social inequality in postsocialism (Bandelj and Mahutga 2010).
} 
Thus gives us David Stark an excellent overview of the predominance of informal practices during socialism, and the reasons why they should persist after the regime change. Indeed, unlike in the capitalist economies, where producers struggle to create new demand niches to sell products and make profits, the challenge in the socialist economy was supply. Because of shortages, it was customers who had to be innovative, relying on interpersonal networks to get what they needed. A second economy-the production, consumption, distribution, and exchange of goods outside of the state regulationdeveloped, contributing to the consolidation of two distinct spheres, the official and the unofficial. Indeed, the decoupling of formal and informal spheres was part of everyday life and one of the core features of lived socialism (Verdery 1996; Creed 1998). The second economy was sustained by a practical logic: in order to achieve economic goals, one is best served by circumventing the official rules. Indeed, the official rules were more or less ceremonial, and even those who were supposedly their guardians, such as officials in public offices or administrators in enterprises, were themselves aware of widespread informality, or paradoxically, even encouraged it. As Borocz (2000, p. 362) reveals for Hungary:

Informality was so powerful a contextual feature of the Hungary of the 1960s that even the much-discussed series of concessions made by the Kadar regime operated entirely in the realm of political informality, producing the oxymoronic phenomenon of judicial informality. The formal Stalinist restrictions and prescriptions on social and economic life - the object of the revolution of 1956 - were rarely revoked: The essence of the Kadarist innovations of the sixties was an informal, tacit understanding that those formal rules and regulations might not be enforced. Thus, many Stalinist rules remained in effect but were rarely administered.

The persistence and bolstering of informality in postsocialism aligns with those accounts that emphasize path dependency and the ways in which structures inherited from before and during the state-socialist period influence how capitalism is being built, so that transformations occur out of the ruins of the former regime and often result in reproduction rather than social change (Stark 1992; Szelenyi and Kostello 1996; Stark and Bruszt 1998). These institutional accounts see economic transformation from socialism to capitalism as a process that depends on experimentation and evolutionary learning and incorporates existing social and economic networks and forms of practice (Kogut 1996; Stark 1992, 1996; Stark and Bruszt 1998; Kogut and Zander 2000; Spicer et al. 2000; McDermott 2002). Moreover, while formal institutions can be changed, especially under pressure from external imperatives, such as the promise of the European Union membership for Central Europe and the Baltics, or repaying of IMF loans, the informal rules and practices are more resistant, in particular when new structural conditions of partial reform reinforce their utility.

As the regime collapsed and in the uncertainty that ensued, the informality continued to be an asset, as it was during socialism where, for instance, informal managerial networks increased company managers' maneuvering space, enabling multiple complex and creative strategies of economic behavior (Stark 1996). Still, coupled with legitimate greed and politicization of economy, informality has also become an increasing liability, supporting double dipping and opportunism, and, on the whole, undermining attempts to build credible market institutions and rule of law. 
How can we assess the pervasiveness and nature of informality in postsocialism? We have to approach this question keeping in mind the two meanings of informality I have suggested: as practice of relying on social relations in the economy in the vein of network economic sociology but also as a logic of action, informality-as-a-way-ofdoing-things. A special journal issue on informality in postsocialism (Polese and Rodgers 2011) provided a series of case studies from different countries. The papers build on the literature on the role of social networks in reciprocity, informal exchange, and mutual aid as characteristic of household strategies in dealing with social and economic change since the end of the Soviet Union (Ledeneva 1998; Caldwell 2004; Dunn 2004; Patico 2008; Stenning et al. 2010). They also “demonstrate an appreciation that informal economic practices have not and did not emerge simply after the collapse of the formal structures of the socialist order in 1989 and 1991... Rather, many informal economic practices, witnessed today, developed in the late socialist period and have in fact persisted and played significant roles in shaping the emerging logic(s) of the post-socialist order(s)" (Polese and Rodgers 2011, p. 613; cf. Rasanayagam 2011).

Findings in Bruns and colleagues (2011) confirm the inter-related nature of informal and economic spheres, outlining how large amounts of the informal economic activities across the EU external borders necessarily depend on "negotiation" with the formal organs of respective states. This suggests that informality in postsocialism goes hand in hand with politicization of the economy and that the two reinforce each other.

Aside from case studies, there also exist attempts to quantify the informal economy in postsocialist countries. Measuring informality is notoriously difficult (Portes and Haller 2005), and there are different manifestations of it that can hardly be quantified. More successful are attempts to measure informal economy (as a subset of informality writ-large). Informal or shadow economy is often defined as "the phenomena whose main shared characteristic is that they escape taxation, registration, regulation and many other forms of public scrutiny in the context where similar activities are supposed to be and, to a certain extent, are taxed, registered, regulated and available for public scrutiny" (Borocz 2000, p. 354).

Schneider (2006, p. 5) collected data for most of the world economies on their shadow economy. In his definition,

the shadow economy includes all market-based legal production of goods and services that are deliberately concealed from public authorities for the following reasons: to avoid payment of income, value added or other taxes; to avoid payment of social security contributions; to avoid having to meet certain legal labor market standards, such as minimum wages, maximum working hours, safety standards, etc.; or to avoid complying with certain administrative procedures, such as completing statistical questionnaires or other administrative forms.

These data, summarized in Table 1, reveal that the shadow economy in postsocialist countries is relatively sizable, much closer to Latin America and Africa than to the Western developed economies (rich OECD countries). 
Table 1 Estimate of shadow economy in postsocialist countries compared to other regions

\begin{tabular}{|c|c|c|c|}
\hline \multirow[t]{2}{*}{ Country } & \multicolumn{3}{|c|}{$\begin{array}{l}\text { Shadow economy (in \% of official GDP) using the MIMIC and currency } \\
\text { demand method }\end{array}$} \\
\hline & $1999 / 00$ & $2001 / 02$ & $2002 / 03$ \\
\hline Albania & 33 & 35 & 35 \\
\hline Bosnia and Herzegovina & 34 & 35 & 37 \\
\hline Bulgaria & 37 & 37 & 38 \\
\hline Croatia & 33 & 34 & 35 \\
\hline Czech Republic & 19 & 20 & 20 \\
\hline Estonia & 38 & 39 & 40 \\
\hline Hungary & 25 & 26 & 26 \\
\hline Latvia & 40 & 41 & 41 \\
\hline Lithuania & 30 & 31 & 33 \\
\hline Macedonia, FYR & 34 & 35 & 36 \\
\hline Moldova & 45 & 47 & 49 \\
\hline Poland & 28 & 28 & 29 \\
\hline Romania & 34 & 36 & 37 \\
\hline Russian Federation & 46 & 48 & 49 \\
\hline Serbia and Montenegro & 36 & 37 & 39 \\
\hline Slovak Republic & 19 & 19 & 20 \\
\hline Slovenia & 27 & 28 & 29 \\
\hline Ukraine & 52 & 54 & 55 \\
\hline Postsocialist countries (average) & 34 & 35 & 36 \\
\hline Rich OECD countries (average) & 17 & 17 & 16 \\
\hline Africa (average) & 41 & 42 & 43 \\
\hline Latin America (average) & 41 & 42 & 43 \\
\hline Asia (average) & 28 & 29 & 30 \\
\hline
\end{tabular}

Regional groupings follow Schneider (2006)

Source: Schneider (2006)

While the numbers from Schneider are telling, they do not reveal the extent of the ethos of informality, or informality-as-a-way-of-doing-things. These numbers do not show the extent to which there exists the moral predominance of informality, ${ }^{6}$ in contrast to Weberian states characterized by moral predominance of formality. The issue is not simply that informal economy is pervasive so better sanctioning, for instance, may eliminate it. It is that "informality rules" (Borocz 2000, p. 348) and it has become the modus operandi that penetrates the polity, economy, and society.

One manifestation of this normative pervasiveness, as opposed to simply behavioral outcomes, is that while the informal sector is usually defined as that outside of the purview of the state, informality in postsocialism is equally pervasive inside the state as

\footnotetext{
${ }^{6}$ I transpose here the phrase that Borocz (2000) uses when he discusses the moral imperative of formality.
} 
it is outside the state: reliance on nepotistic social relations, blurring of economic and political roles, hiring relatives to work on state commissions, inefficient work practices for handling personal matters during work time, or using extensive sick leave because a doctor friend wrote a note for it. This means that most of the population (or their relatives) simultaneously exist in the formal and informal sectors. It is not (only) vulnerability to exploitation (Portes and Haller 2005) that is a liability of informality in postsocialism. It is exclusion from opportunities if you choose not to partake in the informal activities (not taking bribes/provisions, not doing favors to people in power, etc.).

Table 2 Importance of political connections for success

\begin{tabular}{|c|c|c|c|}
\hline & Before 1989* & 2006 & 2010 \\
\hline Albania & 30 & 16 & 24 \\
\hline Bosnia & 12 & 28 & 32 \\
\hline Bulgaria & 28 & 19 & 24 \\
\hline Croatia & 20 & 36 & 40 \\
\hline Czech Rep & 48 & 15 & 17 \\
\hline Estonia & 14 & 13 & 15 \\
\hline Hungary & 18 & 15 & 22 \\
\hline Latvia & 15 & 15 & 17 \\
\hline Lithuania & 15 & 10 & 16 \\
\hline Macedonia & 14 & 40 & 48 \\
\hline Moldova & 8 & 10 & 6 \\
\hline Montenegro & 13 & 28 & 28 \\
\hline Poland & 34 & 26 & 15 \\
\hline Romania & 13 & 10 & 14 \\
\hline Russia & 7 & 15 & 11 \\
\hline Serbia & 22 & 28 & 40 \\
\hline Slovakia & 30 & 16 & 26 \\
\hline Slovenia & 22 & 26 & 28 \\
\hline Ukraine & 11 & 17 & 16 \\
\hline Postsocialist average & 20 & 20 & 23 \\
\hline France & & & 12 \\
\hline Germany & & & 8 \\
\hline Great Britain & & & 3 \\
\hline Sweden & & & 3 \\
\hline West average & & & 6.5 \\
\hline
\end{tabular}

Numbers reflect the percentage of those who answered that political connections were the most important factors to succeed in their country, answering the following Life in Transition Survey question: In your opinion, which of the following factors is the most important to succeed in our country now? 1) Effort and hard work; 2) Intelligence and skills; 3) By political connections; 4) By breaking the law; 5) Other Source: Life in Transition Surveys (EBRD 2015)

*In 2006, respondents were asked to assess the situation before 1989 in retrospect 
Table 3 Perceptions about prevalence of unofficial payments

\begin{tabular}{|c|c|c|}
\hline & Postsocialist & West \\
\hline Interacting with the road police & 11 & $<1$ \\
\hline Receiving medical treatment & 22 & 2 \\
\hline Receiving public education & 7 & $<1$ \\
\hline Obtaining official documents & 6 & $<1$ \\
\hline
\end{tabular}

The table reports average percent reporting "Always" or "Usually", across countries by region, in response to Life in Transition Survey Question: How often do people like you make unofficial payments when... [listing the activities reported above in separate questions]. Postsocialist includes Albania, Bosnia, Bulgaria, Croatia, Czech Republic, Estonia, Hungary, Latvia, Lithuania, Macedonia, Moldova, Montenegro, Poland, Romania, Russia, Serbia, Slovakia, Slovenia, and Ukraine. West includes France, Germany, Great Britain and Sweden Source: Life in Transition Surveys for 2010 (EBRD 2015)

In my view, the rule of informality in postsocialism, instead of law, grew out of established socialist practices, has been bolstered in the capitalist transition purgatory, and has become more perverse. While informality in socialism often facilitated efficiency (Stark 1996), informality in postsocialist capitalism often borders on corruption. Informality also goes hand in hand with politicization of economy and economization of polity. Politically connected entrepreneurs (aka tycoons or crony capitalists) double dip, and state officials use collective resources for private economic advancement. They leverage their power in the redistributive economy to gain an unfair advantage in the market place. They strip the state of resources, often knowingly, sometimes unknowingly and due to incompetence, and the fledging state capacity is additionally undermined, contributing to a vicious circle. Some further evidence from public opinion, as reported in Life in Transition Surveys (EBRD 2015) shows that a significant proportion of respondents from postsocialist countries believe that political connections are still quite important for success in their country (Table 2). Moreover, perceptions of and concrete experience with informal arrangements is substantially more prevalent in postsocialist than in Western European countries, and has increased, not decreased, over time (see Tables 3 and 4).

Table 4 Experience with unofficial payments

\begin{tabular}{lll}
\hline & Postsocialist & West \\
\hline Interacting with the road police & 24 & 4 \\
Receiving medical treatment & 22 & 5 \\
Receiving public education & 10 & 3 \\
Obtaining official documents & 10 & 5 \\
\hline
\end{tabular}

The table reports average percent reporting Yes, across countries by region, in response to Life in Transition Survey Question: Did you or a member of your household make an unofficial payment when [listing the activities reported above in separate questions]. Postsocialist includes Albania, Bosnia, Bulgaria, Croatia, Czech Republic, Estonia, Hungary, Latvia, Lithuania, Macedonia, Moldova, Montenegro, Poland, Romania, Russia, Serbia, Slovakia, Slovenia, and Ukraine. West includes France, Germany, Great Britain and Sweden Source: Life in Transition Surveys for 2010 (EBRD 2015) 


\section{Conclusions}

I have argued that an institutional analysis of postsocialist capitalism as a moral project reveals the following core features:

1. Embrace of greed as a principle of behavior, in tune with the neoliberal mantra, and legitimized before formal institutional foundations of capitalism take hold;

2. Informality - as structures of informal social relations in economy but also as a modus operandi, as-a-way-of-doing-things in political and economic life - continued from the socialist past, and bolstered in devious ways because of legitimate greed and the structural conditions of partial reform;

3. Lack of state autonomy, because of severe politicization of economy, and overlapping of the same self-advancing actors (and their relations) in political and economic roles, rather than productive relationships among state, economy, and society, as when state exhibits embedded autonomy and moral imperative of formality, not informality, prevails.

The outlined features do not exist independently from one another but reinforce each other. The moral predominance of informality and self-serving greed undermine state autonomy, as does politicization of economy bolstered by informality and greed. The overlapping of features also reflects the overarching goal of my analysis to think of postsocialist capitalism as a structural-political-cultural configuration, and as a moral project. I argued that East European transformations need to be recognized not only as an instance of grand institutional change but also as creation of moralized markets that helped construct the moral order of postsocialist capitalism. Neoliberal advisers may not have been right about the feasibility of quick mass privatization, but their message was loud and clear about the need to create self-regulating markets, which legitimized self-serving behavior and greed. The neoliberal prescriptions helped to mold the postsocialist economy to their image, and socialize postsocialist subjects into free-market actors. I should allow here for the possibility that a more civilizing message about the power of markets penetrated some countries. As Eyal (2000) argues, in the Czech Republic in early transition, public intellectuals promoted a different spirit of capitalism, linking the building of capitalist institutions to a high moral duty. Investigating such differentiation, and ability to sustain it over time in the neoliberal era, would prove fertile as a way of gauging the ideal type of postsocialist capitalism presented here against its differentiated empirical instantiations. What Eyal's analysis has in common with mine is that we both resurrect the importance of cultural underpinnings alongside regulatory institutions of capitalism.

The question remains of to what extent these features of postsocialist capitalism that I identified, using conceptual tools of economic sociology, are not simply a reflection of long duree developments of countries in the (semi)periphery, as proposed by the world systems perspective. I have recognized an imprint of neoliberal globalization in shaping postsocialist capitalism, but globalization is not a new process and it has contributed to the position of societies in the global system of unequal exchange. This is a legitimate question and a broad scale, over time, empirical regional comparative effort is necessary to adjudicate it. What I offered is the view that the simultaneity and rapidity of privatization, deregulation, democratization, and neoliberal globalization 
created a specific context for postsocialist transformations, which presented this region with challenges unlike those that accompanied economic and political transformations in other (semi)peripheral states of East Asia, Latin America or China. I offer that this specific context of transformation, together with particularities of the socialist arrangements (that persisted and were bolstered in novel ways), has rendered the kind of informality and structural chasms that undermine state autonomy, which we can identify as particular to postsocialist capitalism.

Finally, what about the implications of my analysis for postsocialist economic development? As concerns features of the state/society/economy relationship, political scientists and sociologists largely agree that state capacity and embedded autonomy are crucial for economic development, which suggests that undermined state autonomy in postsocialist capitalism poses development challenges in the long run. Even with formal institutions of capitalism put in place, the major challenge is to align them with practice. Formal institutions need their substantive legitimacy (Bandelj 2009) but widespread informality undermines the coupling of formal rules and behavior.

In Western modern bureaucracies, as theorized by Weber, formality is the norm in social conduct. This is not to say that informality plays a minor role in Western developed states. A whole body of literature in economic sociology on network embeddedness (Smith-Doerr and Powell 2005) speaks to informality's manifestation in widespread reliance on social ties (cf. DiTomaso 2013). However, this literature also points to the paradox of embeddedness, whereby over-reliance on close-knit relations undermines economic performance (Uzzi 1997). Similarly, research on the downsides to social capital lists high demands of reciprocity on insiders, low access to information and opportunities outside of the network, and exclusion of outsiders as liabilities of embeddedness in social relations (Portes and Sensenbrenner 1993). Further, Schrank and Whitford (2011) theorize network failure as a result of too much opportunism or too much ignorance (or competency shortfalls) among network players. As opportunism goes very well with greed, and reliance on informal ties easily stomps over formal contracts, we can infer from the mico- and meso-level arguments about downsides to social capital and networks that, at the macro-scale, widespread postsocialist informality has perverse consequences for development. While informality may have been an asset during socialism and helped weather the uncertainty of gradual reform in the beginning, with efforts toward greater institutional transparency and accountability, and building of state (embedded) autonomy, postsocialist informality-as-a-wayof-doing-things may very well pose a liability in the long run. The challenge is not to strip the postsocialist economies of reliance on informal social arrangements, because this is neither possible nor desirable. The challenge is to re-socialize postsocialist actors into the moral imperative of formality while building the institutions of Weberian state.

Acknowledgments I am most grateful to the Editors and reviewers of Theory and Society for engaging critically with my argument and helping me improve it. I would also like to thank Alejandro Portes for organizing an ASA session on Institutions and Development for which an early version of this article was first prepared, and to thank audiences at conferences in Yokohama and Chicago where later versions were presented. Katelyn Finley provided excellent research assistance. This piece has been long in the making, and inspired by decades of extensive travel to Eastern Europe to visit family. I dedicate it to the memory of my mother. 


\section{References}

Bandelj, N. (2009). The global economy as instituted process: the case of central and Eastern Europe. American Sociological Review, 74(1), 128-149.

Bandelj, N., \& Mahutga, M. C. (2010). How socio-economic changes shape income inequality in central and Eastern Europe. Social Forces, 88(5), 2133-2161.

Bandelj, N., \& Sowers, E. (2010). Economy and state: A sociological perspective. Polity Press.

Barnes, A. (2006). Owning Russia: The struggle over factories, farms, and power. Ithaca, N.Y.: Cornell University Press.

Block, F., \& Evans, P. (2005). State and economy. In N. J. Smelser \& R. Swedberg (Eds.), The Handbook of Economic Sociology (pp. 505-526). 2nd edn. Princeton, NJ: Princeton University Press; New York: Russell Sage Foundation.

Bockman, J. (2011). Markets in the name of socialism. Stanford University Press.

Bockman, J., \& Eyal, G. (2002). Eastern Europe as a laboratory for economic knowledge: the transnational roots of neoliberalism. American Journal of Sociology, 108, 310-352.

Bohle, D., \& Greskovits, B. (2009). Varieties of capitalism and capitalism tout court. European Journal of Sociology, 50, 355-386.

Bohle, D., \& Greskovits, B. (2012). Capitalist diversity on Europe's periphery. Ithaca, NY: Cornell University Press.

Borocz, J. (2000). Informality rules. East European Politics and Societies, 14(2), 348-380.

Boycko, M., Shleifer, A., \& Vishny, R. (1995). Privatizing Russia. Cambridge, Mass.: The MIT Press.

Bruszt, L. (2012). Political regime types and varieties of post-socialist capitalism in the era of globalization. In Varieties of capitalism, types of democracy and globalization, edited by Masanobu Ido. London: Routledge.

Burawoy, M. (1996). The state and economic involution: Russia through a Chinese lens. World Development, 24(6), 1105-1117.

Burt, R. (1992). Structural holes: The social structure of competition. Cambridge: Harvard University Press.

Burt, R. (2004). Structural holes and good ideas. American Journal of Sociology, 110, 349-399.

Caldwell, M. (2004). Not by bread alone: social support in the New Russia. Berkeley, CA: University of California Press.

Collins, R. (1980). Weber's last theory of capitalism: a systematization. American Sociological Review, 45(6), 925-942.

Creed, G. (1998). Domesticating revolution: from socialist reform to ambivalent transition in a Bulgarian village. University Park: Pennsylvania State University Press.

DiTomaso, N. (2013). The American Non-dilemma: racial inequality without racism. New York: Russell Sage.

Dunn, E. C. (2004). Privatising Poland: baby food, big business, and the remaking of labor. New York, NY: Cornell University Press.

Durkheim, E. (1951). Suicide: A study in sociology. New York: Free Press.

EBRD. 2015. Life in transition survey. Available at: http:/www.ebrd.com/what-we-do/economic-researchand-data/data/lits.html. Accessed on November 1, 2015.

Evans, P. (1979). Dependent development: The alliance of multinational, state and local capital in Brazil. Princeton, N.J.: Princeton University Press.

Evans, P. (1995). Embedded autonomy: states and industrial transformation. Princeton, N.J.: Princeton University Press.

Evans, P., \& Rauch, J. (1999). Bureaucracy and growth: a cross-national analysis of the effects of 'Weberian' state structures on economic growth. American Sociological Review, 64, 748-765.

Evans, P., Rueschemeyer, D., \& Skocpol, T. (1985). Bringing the state back in. New York: Cambridge University Press.

Eyal, G. (2000). Anti-Politics and the spirit of capitalism: dissidents, monetarists and the Czech transition to capitalism. Theory and Society 29(1), 49-92.

Feldmann, M. (2007). The origins of varieties of capitalism: lessons from post-socialist transition in Estonia and Slovenia. In B. Hancké, M. Rhodes, \& M. Thatcher (Eds.), Beyond varieties of capitalism. Oxford University Press.

Fourcade, M., \& Healy, K. (2007). Moral views of market society. Annual Review of Sociology, 33, $285-311$. Frye, T. (2000). Brokers and bureaucrats: building market institutions in Russia. Ann Arbor: University of Michigan Press. 
Gerber, T. P., \& Hout, M. (1998). More shock than therapy: market transition, employment, and income in Russia, 1991-1995. American Journal of Sociology, 104(1), 1-50.

Glyn, A. (2006). Capitalism unleashed: finance globalization and welfare. Oxford: Oxford University Press.

Gore, C. (2000). The rise and fall of the Washington consensus as a paradigm for developing countries. World Development, 28(5), 789-804.

Granovetter, M. (1985). Economic action and social structure: the problem of embeddedness. The American Journal of Sociology, 91, 481-510.

Guseva, A. (2008). Into the red: The birth of the credit card market in postcommunist Russia. Stanford, Calif.: Stanford University Press.

Hall, P., \& Soskice, D. (2001). Varieties of capitalism: The institutional foundations of comparative advantage. Oxford University: Press.

Hamm, P., King, L., \& Stuckler, D. (2012). Mass privatization, state capacity, and economic growth in postcommunist countries: firm- and country-level evidence. American Sociological Review, 77(2), 295-324.

Hough, J. F. (2001). The Logic of Economic Reform in Russia. Washington, D.C.: Brookings Institution Press.

King, L. P., \& Szelenyi, I. (2005). Postcommunist economic systems. In Handbook of economic sociology, Neil Smelser and Richard Swedberg, eds (pp. 206-232). Princeton, N.J.: Princeton University Press.

King, L., \& Sznajder, A. (2006). The state-led transition to liberal capitalism: neoclassical, organizational, world systems, and social structural explanations of Poland's economic success. American Journal of Sociology, 112(3), 751-801.

Kogut, B. (1996). Direct investment, experimentation, and corporate governance in transition economies. In R. Frydman, C. Gray, \& A. Rapaczynski (Eds.), Corporate Governance in Central Europe and Russia: Banks, Funds and Foreign Investors (pp. 293-332). Budapest: Central European University Press.

Kogut, B., \& Zander, U. (2000). Did socialism fail to innovate? A natural experiment of the two Zeiss companies. American Sociological Review, 65(2), 169-190.

Krippner, G., \& Alvarez, A. (2007). Embeddedness and the intellectual projects of economic sociology. Annual Review of Sociology, 33, 219-240.

Ledeneva, A.V. (1998). Russia's economy of favours: blat, networking and informal exchange. Cambridge: Cambridge University Press.

McDermott, G. (2002). Embedded politics: industrial networks and institutional. Change in post-communism. Ann Arbor: University of Michigan Press.

Nee, V., \& Lian, P. (1994). Sleeping with the enemy: a dynamic model of declining political commitment in state socialism. Theory and Society, 23(1994), 253-296.

Noelke, A., \& Vliegenthart, A. (2009). Enlarging the varieties of capitalism: the emergence of dependent market economies in East Central Europe. World Politics, 61(4), 670-702.

Nolan, P. (1996). China's rise, Russia's fall: politics, economics, and planning in the transition from Stalinism. New York: St. Martin's Press.

Ostrom, E. (1990). Governing the commons: The evolution of institutions for collective action. Cambridge University Press.

Patico, J. (2008). Consumption and social change in a Post-Soviet middle class. Stanford, CA: Stanford University Press.

Polanyi, K. (1944). The great transformation: The political and economic origins of our time. Beacon Press.

Polanyi, K. (1957). The economy as instituted process. In K. Polanyi, C. Arensberg \& H. Pearson (Eds.), Trade and Market in the Early Empires (pp. 243-270). Glencoe, Ill.: Free Press.

Polese, A., \& Rodgers, P. (2011). Surviving post-socialism: the role of informal economic practices. International Journal of Sociology and Social Policy, 31(11/12), 612-618.

Portes, A., \& Haller, W. (2005). The informal economy. In N. Smelser, \& R. Swedberg (Eds.), The handbook of economic sociology (2nd ed., ). New York: Russell Sage Foundation.

Portes, A., \& Sensenbrenner, J. (1993). Embeddedness and immigration: notes on the social determinants of economic action. American Journal of Sociology, 98, 1320-1350.

Rasanayagam, J. (2011). Informal economy, informal state: the case of Uzbekistan. International Journal of Sociology and Social Policy, 31(11/12), 681-696.

Rona-Tas, A. (1994). The first shall be last? Entrepreneurship and communist cadres in the transition from socialism. American Journal of Sociology, 100, 40-69.

Rutland, P. (2001). Business and the state in contemporary Russia. Boulder, Colo.: Westview Press.

Sachs, J. (1993). Poland's jump to the market economy. Cambridge, Mass.: The MIT Press.

Schneider, F. (2006). Shadow economies and corruption all over the world: what do we really know. IZA DP No. 2315. Available at http://ftp.iza.org/dp2315.pdf

Schrank, A. (2015). Toward a new economic sociology of development. Sociology of Development, $1(2), 25-50$. 
Schrank, A., \& Whitford, J. (2011). The anatomy of network failure. Sociological Theory, 29, 151-177.

Skocpol, T. (1985). Bringing the state back in: strategies of analysis in current research. In P. Evans, D. Rueschmeyer, \& T. Skocpol (Eds.), Bringing the state back. New York: Cambridge University Press.

Smith-Doerr, L. \& Powell, W. (2005). Networks and economic life. In N. Smelser, \& R. Swedberg (Eds.), The handbook of economic sociology (2nd ed.,) (pp. 379-402). New York: Russell Sage Foundation.

Southworth, C. (2004). The development of post-soviet Neo-paternalism in two enterprises in Bashkortostan: how familial-type management moves firms and workers away from labor markets. In L. McCann (Ed.), Russian transformations: challenging the global narrative (pp. 191-208). London: Routledge.

Spicer, A., McDermott, G., \& Kogut, B. (2000). Entrepreneurship and privatization in. Central Europe: the tenuous balance between destruction and creation. Academy of Management Review, 25(3), 630-649.

Staniszkis, J. (1991). The dynamics of breakthrough. Berkeley, Calif.: University of California Press.

Stark, D. (1992). Path dependence and privatization strategies in East Central Europe. East European Societies and Politics, 6(1), 17-54.

Stark, D. (1996). Recombinant property in East European capitalism. American Journal of Sociology, 101, 993-1027.

Stark, D., \& Bruszt, L. (1998). Postsocialist pathways: transforming politics and property in east Central Europe. Cambridge, Mass.: Cambridge University Press.

Stark, D., \& Vedres, B. (2012). Political holes in the economy: the business network of partisan firms in Hungary. American Sociological Review, 77(5), 700-722.

Stenning, A., Smith, A., Rochovska, A. \& Swiatek, D. (2010). Domesticating neo-liberalism: spaces of economic practice and social reproduction in post-socialist cities. Malden, MA: Blackwell.

Stiglitz, J. (2000). "Whither reform? Ten years of transition. In B. Pleskovic, \& J. Stiglitz (Eds.), Annual World Bank Conference on Economic Development (pp. 27-56). Washington, D.C.: World Bank.

Streeck, W. (2010). Taking capitalism seriously: towards an institutionalist approach to contemporary political economy. Socio-Economic Review, 4, 1-31.

Szelenyi, I., \& Kostello, E. (1996). The market transition debate: toward a synthesis? American Journal of Sociology, 101(4), 1082-1096.

Uzzi, B. (1997). Social structure and competition in interfirm networks: the paradox of embeddedness. Administrative Science Quarterly, 42, 35-67.

Verdery, K. (1996). What was socialism and what comes next? Princeton, N.J.: Princeton University Press.

Wade, R. (1990). Governing the market: economic theory and the role of government in east Asian industrialization. Princeton University: Press.

Wang, S. (1995). The rise of the regions: fiscal reform and the decline of central state capacity in China. In In The waning of the communist state, edited by Andrew walder. Berkeley: University of California Press.

Weber, M. (1978). Economy and society. Berkeley and Los Angeles: University of California Press.

Williamson, J. (1993). Democracy and the Washington consensus. World Development, 21, 1329-1336.

Woodruff, D. (1999). Money unmade: barter and the fate of Russian capitalism. Ithaca, N.Y.: Cornell University Press.

Zelizer, V. (2005). The purchase of intimacy. Princeton University Press.

Nina Bandelj is Professor of Sociology, Equity Advisor to Dean, and Co-Director of the Center for Organizational Research at the University of California, Irvine. Her current research investigates the social and cultural bases of economic phenomena, emotions in economy, determinants and consequences of neoliberal globalization, and inequality and economic attitudes in postsocialist Europe. Bandelj's books include From Communists to Foreign Capitalists: The Social Foundations of Foreign Direct Investment in Postsocialist Europe (2008), Economy and State: A Sociological Perspective (with Elizabeth Sowers, 2010), The Cultural Wealth of Nations (edited with Frederick F. Wherry, 2011) and Socialism Vanquished, Socialism Challenged: Eastern Europe and China, 1989-2009 (edited with Dorothy Solinger, 2012). 